\title{
AKIBAT HUKUM PEMBATALAN PERKAWINAN KARENA WALI NIKAH YANG TIDAK BERHAK TERHADAP KEDUDUKAN ANAK DAN HARTA BERSAMA MENURUT HUKUM ISLAM
}

\author{
Yulianti Maulidya \\ (Mahasiswa Program S1 Fakultas Hukum Universitas Tarumanagara) \\ (E-mail: yuliantimaulidya22@gmail.com) \\ Imelda Martinelli \\ (Corresponding Author) \\ (Dosen Hukum Fakultas Hukum Universitas Tarumanagara, Meraih Sarjana Ilmu Hukum dari \\ Fakultas Hukum Universitas Tarumanagara, Magister Ilmu Hukum dari Fakultas Hukum \\ Universitas Tarumnagara) \\ (E-mail: imeldam@fh.untar.ac.id)
}

\begin{abstract}
Marriage is a physical and spiritual bond between man and woman who become husband and wife creating the happy and eternal family in the name of God Almighty. To conduct a marriage, the prospective groom and bride must meet marriage terms and conditions, or else the marriage itself may be cancelled. The cancellation of marriage is one way of breaking the bond which requirements and principles are flawed. In the provisions of article 71 letter (e), the Islamic law compilation decrales that the marriage held without an authorized guardian will result on abolishment or be considered never exist. Neverthless, the cancelled marriage does not abolish the parental obligation of the children. The child remains legitimate and they are under their parents responsibility. Meanwhile, in the case of shared assets, in Islamic law, husband and wife can choose to use the method of Ash Sulh (negotiation), 'Urf (customary law), and the last option is Qadha (justice).
\end{abstract}

Keywords: legal consequences, cancellation of marriage, position of children, shared assets. 


\section{PENDAHULUAN}

\section{A. Latar Belakang}

Manusia merupakan makhluk sosial, makhluk yang di dalam hidupnya tidak bisa melepaskan diri dari pengaruh manusia lainnya. Manusia juga dikatakan makhluk sosial karena pada diri manusia ada dorongan untuk berhubungan (interaksi) dengan orang lain. Salah satu dari terwujudnya keinginan manusia untuk berinteraksi adalah dengan melakukan perkawinan. Perkawinan merupakan suatu hal yang penting dalam realita kehidupan umat manusia. Dengan adanya perkawinan, rumah tangga dapat ditegakkan dan dibina sesuai dengan norma agama dan tata kehidupan masyarakat. Dalam rumah tangga berkumpul dua insan yang berlainan jenis (suami dan istri), mereka saling berhubungan agar mendapat keturunan sebagai penerus generasi. ${ }^{1)}$

Pasal 28B ayat (1) Undang-Undang Dasar 1945 menyatakan bahwa setiap orang berhak membentuk keluarga dan melanjutkan keturunan melalui perkawinan yang sah. Artinya setiap warga Negara Indonesia berhak melakukan perkawinan yang bertujuan untuk mendapatkan keturunan. Dengan dilakukannya perkawinan, maka akan didapat keturunan yang sehat jasmani, rohani dan mampu menjadi generasi penerus yang tangguh. Perkawinan juga akan mengahasilkan suatu organisasi terkecil di dalam sebuah Negara.

Perkawinan di Indonesia diatur dalam suatu Undang-Undang Perkawinan Nasional, yaitu Undang-Undang Nomor 1 Tahun 1974 (selanjutnya disingkat UUP) dan untuk pelaksanaannya dikeluarkan suatu Peraturan Pemerintah Republik Indonesia Nomor 9 Tahun 1975 yang mengatakan bahwa UUP mulai berlaku secara efektif sejak tanggal 1 Oktober 1975. Hal ini berarti sejak saat itu pula secara yuridis formal berlaku suatu hukum nasional yang mengatur masalah perkawinan di Indonesia dan dengan demikian secara resmi menghapus segala peraturan hukum perkawinan yang berlaku sebelumnya.

Pasal 1 UUP menyatakan bahwa perkawinan sebagai ikatan lahir batin antara seorang pria dengan seorang wanita sebagai suami istri dengan tujuan

1) Abdul Manan, Aneka Masalah Hukum Perdata Islam di Indonesia, (Jakarta: Kencana, 2008), hal. 1. 
membentuk keluarga (rumah tangga) yang bahagia dan kekal berdasarkan Ketuhanan Yang Maha Esa. Oleh karena perkawinan itu merupakan ikatan lahir dan batin dengan tujuan membentuk keluarga yang bahagia dan kekal, maka bagi bangsa Indonesia suatu perkawinan dinilai bukan hanya untuk memenuhi kebutuhan biologis semata, akan tetapi merupakan sesuatu yang bersifat sakral dan suci. Ketentuan dalam Pasal 2 ayat (1) UUP juga menyatakan bahwa perkawinan adalah sah, apabila dilakukan menurut hukum masing-masing agamanya dan kepercayaannya itu. UUP memandang perkawinan tidak hanya dilihat dari aspek formal semata-mata, melainkan dari aspek agama. ${ }^{2)}$ Aspek agama menetapkan tentang kebebasan suatu perkawinan, sedangkan aspek formalnya menyangkut aspek administratif, yaitu pencatatan perkawinan. Menurut UUP, kedua aspek ini harus terpenuhi keduanya, bila perkawinan hanya dilangsungkan menurut ketentuan hukum, tanpa memperhatikan unsur agama, perkawinan dianggap tidak sah, sebaliknya, apabila perkawinan dilakukan hanya memperhatikan unsur hukum agama saja, tanpa memperhatikan atau mengabaikan Undang-Undang (hukum Negara), maka perkawinan dianggap tidak sah. ${ }^{3)}$

Di samping peraturan perundang-undangan yang disebutkan di atas, dimasukkan pula dalam pengertian UUP dalam bahasan ini aturan atau ketentuan yang secara efektif telah dijadikan oleh hakim di Pengadilan Agama sebagai pedoman yang harus diikuti dalam penyelesaian perkara perkawinan bagi pemeluk agama Islam, yaitu Kompilasi Hukum Islam di Indonesia yang penyebarluasannya dilakukan melalui Instruksi Presiden RI Nomor 1 Tahun 1991 tentang Kompilasi Hukum Islam (selanjutnya disingkat KHI). ${ }^{4}$ )

Perkawinan bertujuan untuk mewujudkan kehidupan rumah tangga yang sakinah, mawaddah dan rahmah. Menurut hukum Islam, pengertian perkawinan itu adalah akad atau persetujuan calon suami dan calon istri, karenanya

2) Salim HS. Pengantar Hukum Perdata Tertulis (BW), (Jakarta: Sinar Grafika, 2002), hal. 61 .

3) Wahono Darmabrata, Tinjauan Undang-Undang No. 1 Tahun 1974, tentang Perkawinan Beserta Undang-Undang dan Peraturan Pelaksanaannya, (Jakarta: Gitama Jaya, 2003), hal. 102. hal. 21 .

4) Amir Syarifuddin, Hukum Perkawinan Islam di Indonesia, (Jakarta: Kencana, 2007), 
berlangsungnya harus melalui ijab dan qabul atau serah terima. ${ }^{5)}$ Pengertian perkawinan menurut Pasal 2 KHI, bahwa perkawinan menurut hukum islam adalah pernikahan, yaitu akad yang sangat kuat atau mitssaqan ghalidzan untuk mentaati perintah Allah dan melaksanakannya merupakan ibadah. Di dalam ayatayat Alquran disebutkan bahwa hidup berpasang-pasangan adalah merupakan pembawaan naluriah manusia dan makhluk hidup lainnya, bahkan segala sesuatunya diciptakan berjodoh-jodoh. Hal ini disebutkan dalam salah satu ayat Alquran yaitu surat Adz-Dzariyat ayat 49: ${ }^{6}$

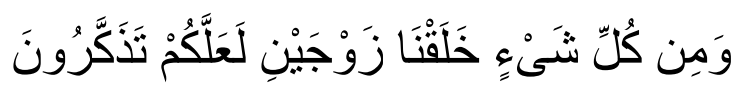

Artinya: "Dan segala sesuatu kami ciptakan berpasang-pasangan supaya kamu mengingat kebesaran Allah.” (QS. Adz-Dzariyat: 49)

Dengan hidup berpasang-pasangan itulah keturunan manusia dapat berlangsung sebagaimana ditegaskan dalam Alquran surat An-Nisa ayat 1:

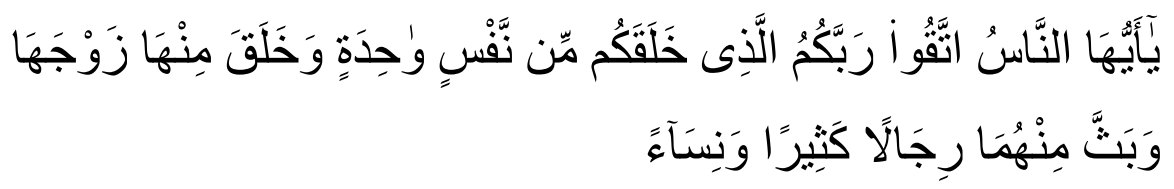

Artinya: "Hai sekalian umat manusia bertaqwalah kamu kepada Tuhanmu yang telah menciptakan kamu dari seorang diri (Adam) dan daripadanya Allah menciptakan pasangannya (Hawa) dan daripada keduanya Allah mengembangbiakan laki-laki dan perempuan yang banyak..." (QS. AnNisa: 1)

Disebutkan pula dalam Hadis Rasul mengenai anjuran pada kita untuk melakukan perkawinan, yaitu Hadis Rasul Muttafaqun Alaihi atau Jamaah Ahli Hadis, yang artinya: ${ }^{7)}$

a. "Hai pemuda barang siapa yang mampu diantara kamu serta berkeinginan hendak nikah (kawin), hendaklah ia itu kawin (nikah), karena sesungguhnya perkawinan itu akan menjauhkan mata terhadap orang yang tidak halal dilihatnya dan akan memeliharanya dari godaan syahwat." (Hadis Rasul Muttafaqun Alaihi)

b. "Dan barang siapa yang tidak kawin hendaklah dia puasa karena dengan puasa hawa nafsunya terhadap perempuan akan berkurang." (Hadis Rasul Jamaah Ahli Hadis)

5) Nashruddin Thoha, Pedoman Perkawinan Islam, (Jakarta: Bulan Bintang, 1967), hal. 10.

\footnotetext{
6) Ahmad Azhar Bashir, Hukum Perkawinan Islam, (Yogyakarta: UII Press, 2002). hal. 9.

${ }^{7)}$ H. Sulaiman Rasyid, Fiqh Islam, (Jakarta: Attahiriyah, 1954), hal. 260.
} 
Dari ketentuan-ketentuan ayat-ayat Alquran dan Hadis tersebut jelaslah bahwa Islam menganjurkan perkawinan. Dengan dilaksanakannnya suatu perkawinan berarti menimbulkan suatu hubungan timbal balik antara suami istri, di mana masing-masing mempunyai hak dan kewajiban yang harus dipenuhi sebagai satu pasangan yang sudah mengikatkan dirinya dalam suatu ikatan yang sah. Keadaan ini jelas berbeda dengan keadaan sebelum dilangsungkannya perkawinan, yang bebas tanpa adanya ikatan dan tanggung jawab terhadap pasangannya.

Sebelum dilaksanakannya perkawinan, ada syarat-syarat yang harus dipenuhi bagi kedua calon mempelai. Pasal 6 UUP mengatur syarat-syarat perkawinan yaitu sebagai berikut: ${ }^{8)}$

(1) Perkawinan harus didasarkan atas persetujuan kedua calon mempelai.

(2) Untuk melangsungkan perkawinan seorang yang belum mencapai umur 21 (dua puluh satu) tahun harus mendapat izin kedua orang tua.

(3) Dalam hal salah seorang dari kedua orang tua telah meninggal dunia atau dalam keadaan tidak mampu menyatakan kehendaknya, maka izin dimaksud ayat (2) pasal ini cukup diperoleh dari orang tua yang masih hidup atau dari orang tua yang mampu menyatakan kehendaknya.

(4) Dalam hal kedua orang tua telah meninggal atau dalam keadaan tidak mampu untuk menyatakan kehendaknya, maka izin diperoleh dari wali, orang yang memelihara atau keluarga yang mempunyai hubungan darah dalam garis keturunan harus ke atas selama mereka masih hidup dan dalam keadaan dapat menyatakan kehendaknya.

(5) Dalam hal ada perbedaan pendapat antara orang-orang yang disebut dalam ayat (2), (3) dan (4) pasal ini, atau salah seorang atau lebih diantara mereka tidak menyatakan pendapatnya, maka Pengadilan dalam daerah hukum tempat tinggal orang yang akan melangsungkan perkawinan atas permintaan orang tersebut dapat memberikan izin

${ }^{8)}$ Ahmad Rofiq, Hukum Islam di Indonesia, (Jakarta: Raja Grafindo Perrsada, Cetakan ke-4, 2000), hal. 72-73 
setelah lebih dahulu mendengar orang-orang tersebut dalam ayat (2), (3) dan (4) pasal ini.

(6) Ketentuan tersebut ayat (1) sampai dengan ayat (5) pasal ini berlaku sepanjang hukum masing-masing agamanya dan kepercayaannya itu dari yang bersangkutan tidak menentukan lain.

Selain syarat-syarat perkawinan yang telah disebutkan di atas, ada pula rukun perkawinan yang harus dipenuhi bagi mereka yang memeluk agama Islam. UUP sama sekali tidak berbicara tentang rukun perkawinan, yang mana syaratsyarat tersebut lebih banyak berkenaan dengan unsur-unsur atau rukun perkawinan. KHI secara jelas membicarakan rukun perkawinan sebagaimana yang terdapat dalam Pasal 14, yaitu: a. Calon Suami; b. Calon Istri; c. Wali nikah; d. Dua orang saksi dan; e. Ijab dan Kabul. Peran wali nikah dalam perkawinan begitu dibutuhkan, sebagaimana telah diatur dalam Pasal 19 KHI, yang menyatakan bahwa wali nikah dalam perkawinan merupakan rukun yang harus dipenuhi bagi calon mempelai wanita yang bertindak untuk menikahkannya.

Yang dimaksud dengan wali secara umum adalah seseorang yang karena kedudukannya berwenang untuk bertindak terhadap dan atas nama orang lain. Dapatnya dia bertindak terhadap dan atas nama orang lain itu adalah karena orang lain itu memiliki kekurangan pada dirinya yang tidak memungkinkan ia bertindak sendiri secara hukum, baik dalam urusan bertindak atas harta atau atas dirinya. Keberadaan seorang wali dalam akad nikah adalah suatu yang mesti dan tidak sah akad perkawinan yang tidak dilakukan oleh wali. Wali itu ditempatkan sebagai rukun dalam perkawinan menurut kesepakatan ulama secara prinsip. ${ }^{9)}$

Memang tidak ada satu ayat Alquran pun yang jelas secara ibarat al-nash yang menghendaki keberadaan wali dalam akad perkawinan. Namun dalam Alquran terdapat petunjuk nash yang ibarat-nya tidak menunjuk kepada keharusan adanya wali, tetapi dari ayat tersebut secara isyarat nash dapat dipahami menghendaki adanya wali, yaitu sebagai berikut: ${ }^{10)}$

Surat Al-Baqarah ayat 232:

9) Amir Syarifuddin, Hukum Perkawinan Islam di Indonesia Antara Fiqh, Munakahat dan Undang-Undang Perkawinan, (Jakarta: Fajar Interpratama Offset, 2007), hal. 69.

${ }^{10)}$ Ibid., hal 70 . 


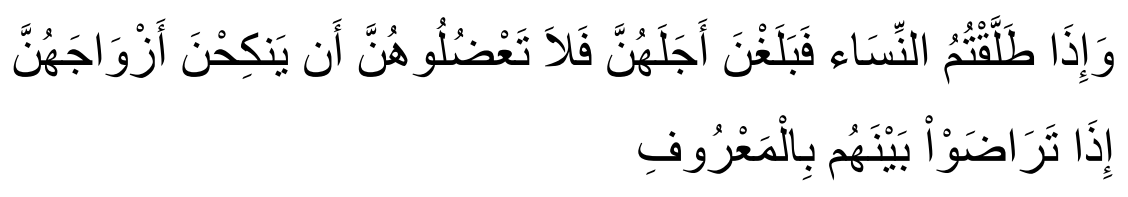

Artinya: "Dan bila kamu telah menalak istrimu, lalu habis iddahnya, maka janganlah kamu (para wali) menghalangi mereka kawin dengan bakal suami mereka, apabila telah terjalin kecocokan di antara mereka." (QS. AlBaqarah: 232)

Surat Al-Baqarah ayat 221:

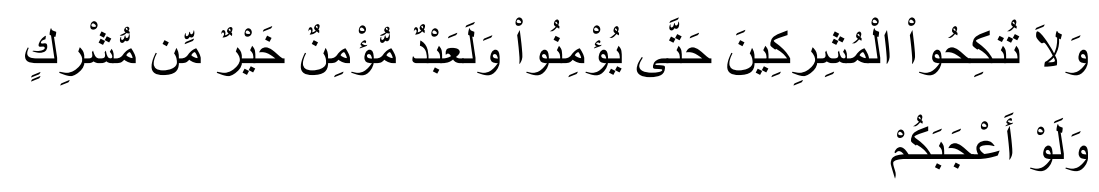

Artinya: "Janganlah kamu mengawinkan anak-anak perempuanmu dengan laki-laki musyrik. Sesungguhnya hamba sahaya mukmin lebih baik dari orang musyrik walaupun ia menarik hatimu." (QS. Al-Baqarah: 221)

Jumhur ulama di samping menggunakan ayat-ayat kelompok pertama di atas sebagai dalil yang mewajibkan wali dalam perkawinan, menguatkan pendapatnya itu dengan serangkaian hadis-hadis di bawah ini, yang artinya: ${ }^{11)}$

1. "Tidak boleh nikah tanpa wali." (HR. Khamsah kecuali Nasai)

2. Dari Sulaiman bin Musa dari Zuhri dari Urwah dari 'Aisyah, sesungguhnya Nabi SAW bersabda, "Siapa saja wanita yang menikah tanpa izin walinya maka nikahnya batal, maka nikahnya batal, maka nikahnya batal. Kemudian jika (suaminya) telah mencampurinya, maka bagi wanita itu berhak memperoleh mahar sebab apa yang telah ia anggap halal dari mencampurinya. Kemudian jika mereka (waliwalinya) berselisih, maka penguasa (hakimlah) yang menjadi walinya." (HR. Khamsah kecuali Nasai)

3. Dari Abu Hurairah RA, ia berkata: Rasulullah SAW bersabda, "Janganlah wanita menikahkan wanita dan janganlah wanita menikahkan dirinya sendiri, karena wanita pezina itu ialah yang menikahkan dirinya sendiri." (HR. Ibnu Majah dan Daruquthni)

Karena keberadaan wali nikah merupakan rukun, maka harus dipenuhi beberapa syarat, yaitu: laki-laki, dewasa, mempunyai hak perwalian dan tidak terdapat halangan perwalian. Dalam Pasal 20 KHI ayat (1) dirumuskan bahwa yang bertindak sebagai wali nikah ialah seorang laki-laki yang memenuhi syarat hukum islam yakni muslim, aqil dan baligh. Dalam pelaksanannya, akad nikah

\footnotetext{
11) Ibid., hal 72-73.
} 
atau ijab dan kabul, penyerahannya dilakukan oleh wali mempelai perempuan atau yang mewakilinya, dan kabul (penerimaan) oleh mempelai laki-laki. ${ }^{12)}$

Dalam hukum Islam, kedudukan wali dalam suatu pernikahan adalah sebagai salah satu rukun nikah yang harus dipenuhi dalam menjalankan prosesi pernikahan. Akan tetapi, sebenarnya dalam hal ini ada perbedaan pendapat atau pandangan ulama yang menetapkan pertimbangan wali dalam prosesi akad pernikahan, maka keberadaan seorang wali masih dianggap suatu hal masih bisa diharuskan, seperti pendapat Imam Syafi'i, beliau berpendapat jika dalam suatu pernikahan tidak ada wali yang menikahkan maka pernikahan tersebut dianggap tidak sah atau menjadi batal. Berlainan dengan pendapat Abu Hanifah, beliau berpendapat bahwa wali bukanlah rukun dalam pernikahan, oleh karena itu pernikahan tanpa adanya seorang wali, maka pernikahan tersebut dihukumi sah. Sedangkan menurut KHI dalam permasalahan wali adalah seperti yang telah dikatakan Imam Syafi'i, bahwa wali ialah rukun pernikahan. Pada dasarnya kematangan jiwalah yang sangat berarti untuk memasuki gerbang rumah tangga. ${ }^{13)}$

Masalah wali nikah sudah diatur dalam Pasal 19 KHI, yaitu tentang perwalian:

Wali nikah dalam perkawinan merupakan rukun yang harus dipenuhi bagi calon mempelai wanita yang bertindak untuk menikahinya. ${ }^{14)}$

Wali nikah ada dua macam, pertama, wali nasab, yaitu wali yang hak perwaliannya didasarkan karena adanya hubungan darah. Ini bisa orang tua kandungnya, dan bisa juga wali $a q r a b$ dan $a b$ 'ad (saudara terdekat atau yang agak jauh). Kedua, wali hakim, yakni wali yang hak perwaliannya timbul, karena orang tua mempelai perempuan menolak ('adal) atau tidak ada, atau karena sebab lain. ${ }^{15)}$ Apabila perkawinan tersebut dilaksanakan dengan wali nikah yang tidak berhak, maka perkawinan tersebut dapat dibatalkan. Seperti yang tertuang di

\footnotetext{
12) Ahmad Rofiq, Op.Cit., hal. 83-84.

13) A. Zuhdi Muhdor, Memahami Hukum Perkawinan: Nikah, Talak, Cerai dan Rujuk,

${ }^{14)}$ Kompilasi Hukum Islam di Indonesia

${ }^{15)}$ Ibid., hal. 85.
} (Bandung: Al-Bayan, 1995), hal. 18. 
dalam Pasal 71 huruf e KHI, bahwa suatu perkawinan dapat dibatalkan apabila perkawinan dilangsungkan tanpa wali atau dilaksanakan oleh wali yang tidak berhak.

Perkawinan yang dibatalkan menimbulkan akibat hukum tidak hanya terhadap pasangan suami istri saja, melainkan terhadap kedudukan anak dan harta bersama yang diperoleh selama perkawinan berlangsung. Pasal 76 KHI menyatakan bahwa batalnya suatu perkawinan tidak akan memutuskan hubungan hukum antara seorang anak dengan orang tuanya. Artinya apabila perkawinan tersebut dibatalkan, maka anak yang lahir dari perkawinan yang dibatalkan tersebut tetap anak sah dan tetap menjadi tanggung jawab kedua orang tuanya.

Masalah harta bersama diatur di dalam Pasal 85 KHI yang menyatakan bahwa adanya harta bersama dalam perkawinan itu tidak menutup kemungkinan adanya harta milik masing-masing suami atau istri. Kemudian Pasal 86 ayat (1) KHI, menyatakan bahwa pada dasarnya tidak ada percampuran harta suami dan harta istri karena perkawinan. Dan Pasal 86 ayat (2) KHI yang menyatakan bahwa harta istri tetap menjadi hak istri dan dikuasai penuh olehnya, demikian juga harta suami tetap menjadi hak suami dan dikuasai penuh olehnya. Dengan demikian, suami maupun istri berhak melakukan perbuatan hukum atas harta masing-masing dalam perkawinan.

Berdasarkan uraian latar belakang di atas, penulis tertarik untuk melakukan kajian lebih lanjut permasalahan hukum tersebut dan menuangkannya dalam bentuk skripsi dengan judul: “AKIBAT HUKUM PEMBATALAN PERKAWINAN KARENA WALI NIKAH YANG TIDAK BERHAK TERHADAP KEDUDUKAN ANAK DAN HARTA BERSAMA MENURUT HUKUM ISLAM"

\section{B. Permasalahan}

Berdasarkan Latar Belakang yang telah diuraikan di atas, maka yang menjadi rumusan permasalahan sebagai berikut: 
Bagaimanakah akibat hukum pembatalan perkawinan karena wali nikah yang tidak berhak terhadap kedudukan anak dan harta bersama menurut Hukum Islam?

\section{Metode Penelitian}

Metode penelitian hukum merupakan suatu proses untuk menemukan aturan hukum, prinsip-prinsip hukum, maupun doktrin-doktrin hukum guna menjawab isu hukum yang akan dihadapi.

\section{Tipe Penelitian}

Tipe penelitian yang akan digunakan oleh Penulis dalam penelitian ini adalah penelitian yuridis normatif. Untuk itu diperlukan penelitian yang merupakan suatu rencana pokok dalam pengembangan ilmu pengetahuan.

Menurut Soerjono Soekanto, pendekatan yuridis normatif yaitu penelitian hukum yang dilakukan dengan cara meneliti bahan pustaka atau data sekunder sebagai bahan dasar untuk diteliti dengan cara mengadakan penelusuran terhadap peraturan-peraturan dan literatur-literatur yang berkaitan dengan permasalahan yang diteliti. ${ }^{16)}$

Metode ini digunakan karena dalam penelitian hukum normatif yang diteliti hanya bahan pustaka atau data sekunder, yang mungkin mencakup bahan hukum primer, sekunder, dan tersier. ${ }^{17)}$ Pendekatan tersebut beranjak dari pandanganpandangan dan doktrin-doktrin yang berkembang di dalam ilmu hukum. ${ }^{18)}$

\section{Sifat Penelitian}

Sifat penelitian yang digunakan dalam penelitian ini adalah bersifat deskriptif, yaitu menggambarkan gejala-gejala di lingkungan masyarakat terhadap suatu kasus yang diteliti. ${ }^{19)}$ Penelitian ini diharapkan dapat memberikan informasi secara lengkap dan jelas mengenai akibat hukum pembatalan perkawinan karena

16) Soerjono Soekanto Dan Sri Mamudji, Penelitian Hukum Normatif Suatu Tinjauan Singkat, (Jakarta: PT. Raja Grafindo Persada, 2003), hal.13-14.

${ }^{17)}$ Soerjono Soekanto, Pengantar Penelitian Hukum, Cetakan ke-3, (Jakarta: Universitas Indonesia, 2006), hal. 52.

18) Ibid., hal 135. 1986), hal 9.

19) Soerjono Soekanto, Metode Penelitian Hukum, (Jakarta: Universitas Indonesia Press, 
wali nikah yang tidak berhak terhadap kedudukan anak dan harta bersama menurut hukum Islam.

\section{Jenis Data}

Secara umum, di dalam penelitian dibedakan antara data yang diperoleh langsung dari masyarakat, dan dari bahan pustaka. ${ }^{20)}$ Jenis data yang digunakan dalam penelitian ini adalah data sekunder yaitu data yang diperoleh dari kepustakaan. Data sekunder yang dipergunakan adalah data sekunder yang bersifat umum, yaitu data yang berupa tulisan-tulisan, data arsip, data resmi dan berbagai data lain yang dipublikasikan. ${ }^{21)}$ Data sekunder tersebut diantaranya peraturan perundang-undangan, buku-buku, majalah, artikel atau bahan-bahan lain yang berhubungan dengan penelitian yang menunjang.

\section{Jenis Bahan Hukum}

Jenis bahan hukum merupakan turunan dari jenis data sekunder berdasarkan kekuatan mengikatnya. Jenis bahan hukum dibagi menjadi tiga. Berikut bahan hukum yang akan digunakan yaitu :

a. Bahan hukum primer, yaitu bahan hukum yang mempunyai kekuatan mengikat berupa peraturan. Lebih lanjut bahan hukum primer dalam penelitian ini adalah Undang-Undang Nomor 1 Tahun 1974 tentang Perkawinan dan Kompilasi Hukum Islam.

b. Bahan hukum sekunder adalah buku teks karena buku teks berisi mengenai prinsip-prinsip dasar ilmu hukum. Bahan hukum sekunder berarti bahan hukum yang erat kaitannya dengan bahan hukum primer dan dapat membantu menganalisa, memahami, dan menjelaskan bahan hukum primer, yang meliputi jurnal, makalah, laporan penelitian dan buku.

c. Bahan hukum tersier, yaitu bahan hukum yang memberikan petunjuk maupun penjelasan atas bahan hukum primer dan sekunder, yang meliputi kamus, biografi, buku tahunan, buku petunjuk, indeks dan lain-lain.

\section{Metode Analisis}

${ }^{20)}$ Soerjono Soekanto, Penelitian Hukum Normatif, Suatu Tinjauan Singkat, (Jakarta: Rajawalipers, 2007), hal.21.

${ }^{21)}$ Soerjono Soekanto, Pengantar Penelitian Hukum, Op.Cit., hal 51. 
Analisis data yang digunakan yaitu analisis kualitatif, yaitu menguraikan dan menginterpretasikan data dalam bentuk kalimat yang baik dan benar untuk memperoleh jawaban singkat yang dirumuskan secara deduktif. Berdasarkan analisis data kualitatif, maka hasil penelitian ini akan diuraikan dalam bentuk kalimat yang disusun secara sistematis, jelas, dan rinci sehingga dapat diinterpretasikan untuk memperoleh suatu kesimpulan secara deduktif untuk menjawab pokok bahasan yang ada.

\section{PEMBAHASAN}

\section{Pembatalan Perkawinan Karena Wali Nikah Yang Tidak Berhak}

Istilah pembatalan perkawinan dalam hukum islam lebih dikenal dengan kata fasakh. Fasakh berasal dari bahasa arab dari akar kata fa-sa-kha yang secara etimologi berarti membatalkan. Bila dihubungkan kata ini dengan perkawinan berarti membatalkan perkawinan atau merusak perkawinan. Dalam arti terminologis ditemukan beberapa rumusan yang hampir bersamaan maksudnya, di antaranya yang terdapat dalam Kamus Besar Bahasa Indonesia (KBBI), berikut: ${ }^{22)}$

Pembatalan ikatan pernikahan oleh Pengadilan Agama berdasarkan tuntutan istri atau suami yang dapat dibenarkan Pengadilan Agama atau karena pernikahan yang telah terlanjur menyalahi hukum pernikahan.

Perdebatan tentang wali nikah dalam suatu akad perkawinan sudah lama dibicarakan oleh para ahli hukum Islam. Sebagian para ahli hukum Islam mengatakan bahwa perkawinan yang dilaksanakan tanpa wali, perkawinan tersebut tidak sah karena kedudukan wali dalam akad perkawinan adalah salah satu rukun yang harus dipenuhi. Sebagian para ahli hukum Islam lainnya mengemukakan bahwa wali dalam suatu akad perkawinan bukanlah suatu rukun yang harus dipenuhi, tetapi sekedar sunnah saja dan perkawinan yang dilaksanakan tanpa hadirnya wali dalam akad perkawinan bukanlah suatu hal yang cacat hukum, perkawinan tersebut tetap sah dan perkawinan itu menjadi tidak batal. $^{23)}$

\footnotetext{
22) Amir Syarifuddin, Op.Cit., hal. 242-245.

23) Abdul Manan, Op.Cit., hal. 58.
} 
Menurut Muhammad Jawad Mughniyah, yang dimaksud wali dalam perkawinan adalah suatu kekuasaan atau wewenang syar'i atas segolongan manusia yang dilimpahkan kepada orang yang sempurna, karena kekurangan tertentu pada orang yang dikuasai itu demi kemaslahatannya sendiri. Sementara, Zahri Hamid menjelaskan bahwa wali nikah adalah seorang laki-laki yang dalam suatu akad nikah berwenang mengijabkan pernikahan calon mempelai perempuan, adanya wali nikah itu merupakan rukun yang harus dipenuhi dalam suatu akad perkawinan. Kedudukan wali sangat penting dan menentukan dalam sahnya perkawinan, dan tidak sah perkawinan tanpa adanya wali nikah. Pengarang kitab Rhaudhah Nadiah menjelaskan bahwa wali adalah mereka yang dekat dengan calon mempelai wanita, dimulai dari yang paling dekat dan seterusnya, jika mereka berhalangan dapat diganti oleh wali hakim. ${ }^{24)}$

Oleh karena keberadaan wali nikah itu merupakan rukun yang harus dipenuhi, maka untuk menjadi wali nikah itu haruslah terpenuhi syarat-syarat yang telah ditentukan oleh syariat Islam dan peraturan perundang-undangan yang berlaku.

Sehubungan dengan hukum perkawinan di Indonesia menganut prinsip bahwa wali nikah merupakan rukun nikah yang harus dipenuhi, maka setiap pernikahan yang dilaksanakan oleh seseorang harus memakai wali dengan urutan kedudukan wali dalam hukum Islam secara benar. Jika perkawinan tersebut tidak memakai wali atau tidak menggunakan wali sesuai dengan urutan kedudukan yang telah ditentukan oleh hukum Islam secara benar, maka perkawinan tersebut cacat hukum dan dikategorikan sebagai nikah bathil atau nikah rusak. Oleh karena itu, bagi mereka yang mengetahui adanya cacat hukum dalam perkawinan tersebut haruslah segera memberitahukan kepada pihak-pihak yang terlibat dalam perkawinan, sehingga perkawinan tersebut dapat segera dimintakan pembatalan pada Pengadilan Agama. ${ }^{25)}$

\footnotetext{
24) Ibid., hal. 59.

25) Ibid., hal. 65.
} 


\section{Akibat Hukum Pembatalan Perkawinan Karena Wali Nikah Yang Tidak Berhak}

\section{a. Kedudukan Anak}

Di dalam Alquran, anak sering disebutkan dengan kata walad-awlaad yang berarti anak yang dilahirkan orang tuanya, laki-laki maupun perempuan, besar atau kecil, tunggal maupun banyak. Karenanya jika anak belum lahir belum dapat disebut al-walad atau al-mawluud, tetapi disebut al-janin yang berarti al-mastuur (tertutup) dan al-khafy (tersembunyi) di dalam rahim ibu. Kata al-walad dipakai untuk menggambarkan adanya hubungan keturunan, sehingga kata al-walid dan al-walidah diartikan sebagai ayah dan ibu kandung. Berbeda dengan kata $i b n$ yang tidak mesti menunjukkan hubungan keturunan dan kata $a b$ tidak mesti berarti ayah kandung. Selain itu, Alquran juga menggunakan istilah thifl (kanak-kanak) dan ghulam (muda remaja) kepada anak, yang menyiratkan fase perkembangan anak yang perlu dicermati dan diwaspadai orang tua, jika ada gejala kurang baik dapat diberikan terapi sebelum terlambat, apalagi fase ghulam (remaja) di mana anak mengalami puber, krisis identitas dan transisi menuju dewasa. Alquran juga menggunakan istilah ibn pada anak, masih seakar dengan kata bana yang berarti membangun atau berbuat baik, secara semantis anak ibarat sebuah bangunan yang harus diberi pondasi yang kokoh, orang tua harus memberikan pondasi keimanan, akhlak dan ilmu sejak kecil, agar ia tumbuh dan berkembang menjadi anak yang memiliki prinsip dan kepribadian yang teguh. ${ }^{26)}$

Akibat hukum dari dibatalkannya perkawinan tidak serta merta menghilangkan kewajiban orang tua untuk menelantarkan anaknya. Baik dalam UUP maupun KHI dengan tegas menyatakan bahwa anak-anak yang dilahirkan dalam perkawinan yang telah dibatalkan dinyatakan tidak berlaku surut, meskipun salah seorang dari orang tuanya beritikad buruk/keduanya beritikad buruk. Ini berdasarkan rasa kemanusiaan dan kepentingan anak-anak sehingga patut untuk

26) Abdul Mustakim, Kedudukan dan Hak-hak Anak dalam Perspektif al-Qur'an, (Artikel Jurnal Musawa, vol. 4 No. 2, Juli-2006), hal. 149-150. 
mendapatkan perlindungan hukum. Hal ini diperkuat dengan firman Allah yang terdapat di dalam surat al-Baqarah ayat 233, yang artinya:

Artinya: "Para ibu hendaklah menyusukan anak-anaknya selama dua tahun penuh, yaitu bagi yang ingin menyempurnakan penyusuan. Dan kewajiban ayah memberi makan dan pakaian kepada para ibu dengan cara ma'ruf. Seseorang tidak dibebani melainkan menurut kadar kesanggupannya. Janganlah seorang ibu menderita kesengsaraan karena anaknya dan seorang ayah karena anaknya, dan waris pun berkewajiban demikian. Apabila keduanya ingin menyapih (sebelum dua tahun) dengan kerelaan keduanya dan permusyawaratan, maka tidak ada dosa atas keduanya. Dan jika kamu ingin anakmu disusukan oleh orang lain, maka tidak ada dosa bagimu apabila kamu memberikan pembayaran menurut yang patut. Bertakwalah kamu kepada Allah dan ketahuilah bahwa Allah Maha Melihat apa yang kamu kerjakan.” (QS. Al-Baqarah: 233)

Pasca pembatalan perkawinan, ada penyesuaian-penyesuain yang harus dilakukan oleh kedua belah pihak (mantan suami dan mantan istri) terhadap kehidupan mereka yang baru. Terutama masalah finansial, apalagi dari perkawinan antara mereka telah dilahirkan anak. Hal ini sesuai dengan hadis Nabi yang diriwayatkan oleh Bukhari Muslim:

Abdullah bin Umar radhiallahu anhuma berkata: Aku mendengar Rasulullah shallallahu 'alaihi wasallam bersabda: "Setiap kalian adalah pemimpin, dan setiap pemimpin akan dimintai pertanggungjawaban atas yang dipimpinnya. Imam adalah pemimpin yang akan diminta pertanggungjawaban atas rakyatnya. Seorang suami adalah pemimpin dan akan dimintai pertanggungjawaban atas keluarganya. Seorang istri adalah pemimpin di dalam urusan rumah tangga suaminya, dan akan dimintai pertanggung jawaban atas urusan rumah tangga tersebut. Seorang pembantu adalah pemimpin dalam urusan harta tuannya, dan akan dimintai pertanggung jawaban atas urusan tanggung jawabnya tersebut." (HR. AlBukhari no. 844 dan Muslim no. 1829)

Berdasarkan ayat Alquran dan kutipan hadis di atas, jelas bahwa orang tua khususnya seorang ayah wajib bertanggungjawab terhadap anak-anak yang dilahirkannya meskipun perkawinan mereka telah dibatalkan oleh hakim.

Anak yang dilahirkan dari perkawinan yang dibatalkan statusnya jelas anak sah sehingga ia berhak atas pemeliharaan dan pembiayaan serta waris. Dalam Pasal 105 KHI menyatakan bahwa "Pemeliharaan anak yang belum mumayyiz. atau belum berumur 12 tahun adalah hak dari ibunya, dan ia berhak untuk 
memilih untuk tinggal dengan ayah atau ibunya setelah ia mumayyiz. Namun biaya pemeliharaan tetap ditanggung oleh ayahnya."

Pembatalan perkawinan tidak berakibat hukum terhadap anak yang dilahirkan dalam perkawinan tersebut. Anak tetaplah tanggung jawab kedua orang tuanya. Hal ini sesuai dengan ketentuan Pasal 28 ayat (2) huruf a yang menyatakan bahwa "Keputusan pembatalan perkawinan tidak berlaku surut terhadap: Anak-anak yang dilahirkan dari perkawina tersebut." Oleh sebab itu, anak-anak yang dilahirkan dari perkawinan yang dibatalkan tersebut masih menjadi tanggung jawab kedua orang tuanya.

Menurut Drs. Slamet, anak-anak yang lahir dari perkawinan yang dibatalkan menurupakan anak sah yang masih memiliki hubungan perdata dengan kedua orang tuanya. Dalam Pasal 47 UUP dikatakan bahwa anak yang belum mencapai umur 18 tahun atau belum pernah melangsungkan perkawinan ada di bawah kekuasaan orang tuanya selama mereka tidak dicabut dari kekuasaannya. Artinya jelas bahwa anak masihlah menjadi tanggung jawab kedua orang tuanya selama ia belum mampu menghidupi dirinya sendiri. ${ }^{27}$

Dalam doktrin Agama Islam, orang tua adalah pihak yang paling bertanggung jawab dengan pendidikan kepada anak-anaknya. Bukan seorang guru, dan ini memang sudah terjadi secara realitas kondisional, bahwa orang yang paling cinta dan kasih sayang itu adalah orang tua kepada anak-anaknya. Hal ini sudah tertulis di dalam ayat-ayat Alquran, di mana orang tua memiliki kewajiban untuk mendidik anak-anak mereka. Dengan didikan orang tua, pertumbuhan anak akan maksimal dalam segi psikis, karena anak sejatinya memiliki ikatan terhadap orang tua mereka. Anak-anak juga tidak bisa dibebankan atas kesalahan orang tuanya. Hubungan suami istri yang perkawinannya dibatalkan tentu akan memutuskan hubungan perdata keduanya, namun tidak dengan hubungan perdata antara anak dan orang tuanya.

Oleh sebab itu, sudah jelas aturannya baik di dalam Alquran, Hadis, Undang-Undang maupun KHI, pembatalan perkawinan tidak mempengaruhi

${ }^{27}$ Penulis. Wawancara, dengan Drs. H. M. Slamet Turhamun, S.H., M.H. selaku Hakim di Pengadilan Agama Tangerang, (Tangerang, 18 Mei 2018). 
hubungan anak dengan orang tuanya. Anak tetap dianggap anak sah dan dinasabkan kepada ayahnya. Ia juga berhak atas pemeliharaan, pembiayaan dan waris dari kedua orang tuanya.

\section{b. Harta Bersama}

Secara bahasa, harta bersama adalah dua kata yang terdiri dari kata "harta" dan "bersama". Menurut bahasa "harta" adalah barang-barang, uang dan sebagainya yang merupakan kekayaan. Atau bisa juga disebut barang-barang milik seseorang, kekayaan berwujud dan tidak berwujud yang bernilai. Harta bersama berarti harta yang digunakan (dimanfaatkan) bersama-sama. ${ }^{28)}$ Baik dalam Alquran maupun Hadis tidak dibicarakan tentang harta bersama, akan tetapi dalam kitab-kitab fiqih ada pembahasan yang dapat diartikan sebagai pembahasan tentang harta bersama, yaitu yang disebut Syirkah atau Syarikah.

Harta bersama atau yang biasanya disebut juga dengan harta gono-gini ini, suami atau istri dapat bertindak untuk berbuat sesuatu atau tidak berbuat sesuatu atas harta bersama tersebut melalui persetujuan kedua belah pihak. Semua harta yang diperoleh suami istri selama dalam ikatan perkawinan menjadi harta bersama baik harta tersebut diperoleh secara tersendiri maupun diperoleh secara bersamasama. Demikian juga harta yang dibeli selama ikatan perkawinan berlangsung adalah menjadi harta bersama. Tidak menjadi suatu permasalahan apakah istri atau suami yang membeli, tidak menjadi masalah juga apakah istri atau suami mengetahui pada saat pembelian itu atau atas nama siapa harta itu harus didaftarkan. ${ }^{29)}$

Apabila perkawinan itu putus, maka suami tidak berhak mengambil kembali mahar yang telah diberikan kepada istrinya tersebut. Hal ini sesuai dengan firman Allah dalam surat an-Nisa ayat 20 yang berbunyi:

Artinya: "Dan jika kamu ingin mengganti isterimu dengan isteri yang lain, sedang kamu telah memberikan kepada seseorang di antara mereka harta yang banyak, maka janganlah kamu mengambil kembali dari padanya

28) Syaikhul Hakim, "Reaktualisasi Pembagian Harta Bersama Dalam Mazhab Syafii Dan Kompilasi Hukum Islam Di Indonesia”, Akademika, Volume 9, Nomor 2, Desember 2015, hal. 161.

29) Ibid., hal. 109. 
barang sedikitpun. Apakah kamu akan mengambilnya kembali dengan jalan tuduhan yang dusta dan dengan (menanggung) dosa yang nyata." (QS. AnNisa: 20).

Ketentuan dalam Pasal 85 KHI menyatakan bahwa dalam perkawinan ada harta bersama dan ada harta milik masing-masing suami atau istri. Terhadap harta kekayaan bersama (gono-gini), tetap merupakan harta bersama yang menjadi milik bersama. Namun harta yang diperoleh sebuah keluarga tidak mesti secara langsung otomatis menjadi harta gono-gini. Hal ini sesuai dengan hadis Nabi yang diriwayatkan Bukhari Muslim:

Dari Aisyah, sesungguhnya Hindun binti Utbah berkata: "Wahai Rasulullah, sesungguhnya Abu Sufyan seorang yang sangat pelit. Dia tidak memberi harta yang cukup untukku dan anakku, kecuali apa yang saya ambil sendiri tanpa sepengetahuannya." Maka Rasulullah bersabda, "Ambillah yang cukup bagimu dan anakmu dengan cara yang ma'ruf." (HR. Bukhari no.5364 dan Muslim no.1714).

Pasal 96 KHI menyatakan bahwa harta bersama suami istri apabila terjadi putusnya perkawinan baik karena kematian atau perceraian maka kepada suami istri tersebut masing-masing mendapat setengah bagian dari harta yang mereka peroleh selama perkawinan berlangsung. Pembagian harta bersama setengah untuk suami dan setengah untuk istri dalam kasus-kasus tertentu dapat dilenturkan mengikat realita dalam kehidupan keluarga di beberapa daerah di Indonesia ini ada pihak suami yang tidak berpartispasi dalam membangun ekonomi rumah tangga. ${ }^{30)}$ Namun ketentuan dalam KHI ini bukanlah suatu putusan hukum yang paten, jika suami istri sepakat membagi harta dengan persentase tertentu, maka kesepakatan dan keridhaan mereka didahulukan. Syariat tidak membagi harta gono-gini ini dengan bagian masing-masing secara pasti, misalnya istri $50 \%$ dan suami $50 \%$. Sebab, tidak ada nash yang mewajibkan demikian baik dari Alquran maupun sunah. Namun pembagiannya bisa ditinjau dari beberapa kemungkinan. ${ }^{31)}$

Metode pembagian harta bersama tidak dibahas dengan jelas baik dalam Alquran maupun dalam literatur kitab-kitab klasik, hal ini disebabkan oleh budaya

${ }^{30)}$ Ibid., hal. 129 .

31) Ustadz Ahmad Sabiq, "Harta Gono-gini dalam Islam", diakses dari https://konsultasisyariah.com/14448-teka-teki-harta-gono-gini.html, pada tanggal 28 Mei 2018. 
bangsa arab yang tidak mengenal adanya pencampuran harta kekayaan yang diperoleh suami maupun istri. Dengan tidak adanya hukum-hukum Islam yang menyatakan secara jelas adanya harta bersama dalam perkawinan, maka Penulis akan memaparkan beberapa kemungkinan dalam pembagian harta gono-gini yang dapat digunakan dalam pembagian harta bersama di mana metode-metode yang akan disebutkan di bawah ini tidak harus selalu berurutan, namun dapat dijadikan pilihan dalam menyelesaikan sengketa pembagian harta bersama, yaitu:

\begin{tabular}{|c|c|c|}
\hline No. & Metode Dalam Islam & Pembagian \\
\hline 1. & Sulh & Berdasarkan Kesepakatan \\
& Suami Istri \\
\hline 2. & 'Urf & Berdasarkan Hukum Adat \\
\hline 3. & Qadha & Berdasarkan Putusan Hakim \\
\hline
\end{tabular}

Sulh sendiri adalah kesepakatan antara suami istri berdasarkan musyawarah atas dasar saling ridha. Dalil pensyariatan perdamaian suami istri antara lain:

Dari Katsir bin Abdillah bin Amr bin Auf al-Muzani, dari bapaknya dari kakeknya, bahwa Rasulullah shallallahu 'alaihi wa sallam bersabda: "Berdamai itu boleh dilakukan antara kaum muslimin, kecuali sebuah perdamaian yang mengharamkan yang halal atau menghalalkan yang haram. Dan kaum muslimin itu tergantung pada syarat mereka, kecuali syarat yang mengharamkan yang halal atau menghalalkan yang haram." (HR. Tirmidzi No.1370, Ahmad 2:366, dan Abu Dawud no. 3594)

Dengan jalan perdamaian ini, pembagian harta gono-gini bergantung pada musyawarah antara suami istri. Bisa jadi suami mendapat 50\% dan istri $50 \%$ atau suami mendapat $30 \%$ dan istri $70 \%$, pun suami bisa mendapat $70 \%$ dan istri $30 \%$, dan boleh pula pembagian dengan nisbah (persentase) yang lain. Semuanya 
dibenarkan syara', selama merupakan hasil dari perdamaian yang telah ditempuh berdasarkan kerelaan masing-masing. ${ }^{32)}$

'Urf, merupakan adat kebiasaan yang berlaku di sebuah masyarakat, sehingga itu menjadi hukum di masyarakat tersebut. Para ulama sepakat 'urf bisa dijadikan salah satu acuan hukum. Dalam salah satu kaidah fikih disebutkan,

\section{العَادَةُ مُحَكََّّةٌُُ}

"Sebuah adat kebiasaan itu bisa dijadikan sandaran hukum."

Qadha, jika tidak ada sulh dan 'urf, barulah masuk dalam sistem terakhir, yaitu qadha. Qadha sendiri adalah keputusan yang ditetapkan oleh hakim setempat tentang masalah yang disampaikan kepadanya. Dalam kondisi ini seorang hakim harus melihat kepada kondisi suami istri tersebut, untuk bisa menentukan pembagian harta gono-gini secara baik. Dan dalam kondisi ini boleh bagi hakim untuk menggunakan hukum perdata yang berlaku di peradilan, selagi tidak bertentangan dengan hukum syariat Islam. ${ }^{33)}$

\section{PENUTUP}

\section{A. Kesimpulan}

Berdasarkan seluruh rangkaian masalah mengenai akibat hukum pembatalan perkawinan karena wali nikah yang tidak berhak terhadap kedudukan anak dan harta bersama menurut hukum islam yang telah diuraikan, permasalahan hukum yang hendak dibahas, data hasil penelitian hingga analisis permasalahan yang telah penulis lakukan, penulis dapat menarik kesimpulan bahwa kedudukan anak tetap bersatatus sebagai anak sah berdasarkan Undang-Undang Perkawinan, Kompilasi Hukum Islam dan fikih, penetapan nasab anak yang lahir dalam perkawinan fasid sama dengan penetapan anak dalam pernikahan sah. Artinya, anak yang lahir dari perkawinan yang dibatalkan tetap disebut anak sah dan memiliki hubungan dengan kedua orang tuanya. Hal ini juga diperkuat dengan ketentuan Pasal 76 KHI yang menyatakan bahwa batalnya suatu

\footnotetext{
32) Ibid.
}

33) Ibid. 
perkawinan tidak akan memutuskan hubungan hukum antara anak dengan orang tuanya.

Oleh sebab itu, anak tetap berhak atas pemeliharaan dan pembiayaan dari orang tuanya. Berkaitan dengan harta bersama setelah perkawinan tersebut dibatalkan, Penulis dapat menarik kesimpulan bahwa harta bersama yang diperoleh selama perkawinan berlangsung dapat dibagi dengan metode yang paling dianjurkan di dalam Islam, yaitu Sulh atau kesepakatan antara suami dan istri yang perkawinannya dibatalkan, apabila kesepakatan tidak tercapai maka dapat menggunakan metode ' $U r f$, yaitu pembagian berdasarkan hukum adat, dengan ketentuan bahwa kedua belah pihak sepakat menggunakan hukum adat sebagai metode pembagian harta bersama mereka. Namun apabila suami istri tidak sepakat menggunakan 'Urf, maka Islam memberikan alternatif terkahir yaitu dengan Qadha, ialah pembagian harta bersama berdasarkan putusan pengadilan. Di mana hakim yang lebih berhak memutus berapa persentase pembagian harta bersama tersebut.

\section{B. Saran}

Berdasarkan apa yang telah disimpulkan oleh penulis, maka penulis dapat memberikan beberapa saran, yaitu:

1. Sebaiknya pasangan yang akan melangsungkan perkawinan tidak mengesampingkan peranan wali nikah yang berhak dalam perkawinan. Karena wali nikah merupakan rukun perkawinan yang harus dipenuhi. Sehingga peristiwa pembatalan perkawinan seperti dalam kasus di atas tidak terjadi apabila proses perkawinan ditempuh dengan prosedur yang telah ditentukan baik secara hukum dan agama.

2. Sebaiknya Kepala Kantor Urusan Agama (KUA) lebih berhati-hati dalam menerima berkas atau dokumen persyaratan perkawinan, khususnya mengenai wali hakim yang harus melalui putusan pengadilan, sehingga perkawinan tersebut menjadi sah dan tidak 
terjadi pembatalan perkawinan yang nantinya akan berakibat hukum terhadap kedudukan anak dan harta bersama.

\section{DAFTAR PUSTAKA}

\section{A. Buku}

Basyir, Ahmad Azhar. Hukum Perkawinan Islam, (Yogyakarta: UII Press, 2002).

Hakim, Syaikhul, "Reaktualisasi Pembagian Harta Bersama Dalam Mazhab Syafii Dan Kompilasi Hukum Islam Di Indonesia”, Akademika, Volume 9, Nomor 2, Desember 2015, hal. 161.

Manan, Abdul. Aneka Masalah Hukum Perdata Islam di Indonesia, (Jakarta: Kencana, 2008).

Mustakim, Abdul, Kedudukan dan Hak-hak Anak dalam Perspektif alQur'an, (Artikel Jurnal Musawa, vol. 4 No. 2, Juli-2006).

Rasyid, Sulaiman. Fiqh Islam, (Jakarta: Attahiriyah, 1964)

Rofiq, Ahmad. Hukum Islam di Indenesia, (Jakarta: Raja Grafindo Persada, 2000).

Salim, HS. Pengantar Hukum Perdata Tertulis (BW), (Jakarta: Sinar Grafika, 2002).

Soekanto, Soerjono. Metode Penelitian Hukum, (Jakarta: Universitas Indonesia Press, 1986).

Soekanto, Soerjono Dan Sri Mamudji, Penelitian Hukum Normatif Suatu Tinjauan Singkat, (Jakarta: PT. Raja Grafindo Persada, 2003).

. Pengantar Penelitian Hukum, (Jakarta: UI Press, 1986).

Soekanto, Soerjono. Pengantar Penelitian Hukum, Cetakan ke-3, (Jakarta: Universitas Indonesia, 2006).

Syarifuddin, Amir. Hukum Perkawinan Islam di Indonesia, (Jakarta: Kencana, 2007).

Thoha, Nashruddin. Pedoman Perkawinan Islam, (Jakarta: Bulan Bintang, 1967). 
Wahono Darmabrata, Tinjauan Undang-Undang No. 1 Tahun 1974, tentang Perkawinan Beserta Undang-Undang dan Peraturan Pelaksanaannya, (Jakarta: Gitama Jaya, 2003).

Muhdor, Zuhdi. Memahami Hukum Perkawinan: Nikah, Talak, Cerai dan Rujuk, (Bandung: Al-Bayan, 1995).

\section{B. Peraturan Perundang-undangan}

Indonesia. Undang-Undang Dasar Negara Republik Indonesia Tahun 1945.

Indonesia. Undang-Undang Nomor 1 Tahun 1974 tentang Perkawinan.

Indonesia. Keputusan Menteri Agama Republik Indonesia Nomor: 154 Tahun 1991 tentang Pelaksanaan Instruksi Presiden Republik Indonesia Nomor 1 Tahun 1991 tentang Penyebarluasan Kompilasi Hukum Islam.

\section{Internet}

Ustadz Ahmad Sabiq, "Harta Gono-gini dalam Islam", diakses dari https://konsultasisyariah.com/14448-teka-teki-harta-gono-gini.html, pada tanggal 28 Mei 2018. 